\title{
FEEDING PREFERENCES OF NIPA-OBLIGATE CRAB Labuanium politum (DE MAN, 1887) IN CAPTIVITY; HERBIVOROUS SHIFT TO OPPORTUNISTIC OMNIVORES
}

\author{
SITI AKMAR KHADIJAH AB RAHIM, NUR AMIRAH MOHAMAD ALWIE* AND AKMA \\ IDDIN MASINI
}

Faculty of Resource Science and Technology, Universiti Malaysia Sarawak, 94300, Sarawak, Malaysia.

*Corresponding author: nuramirahmohamadalwie@yahoo.com.my Submitted final draft: 6 May $2020 \quad$ Accepted: 24 May 2020

http://doi.org/10.46754/jssm.2020.12.007

\begin{abstract}
Labuanium politum is a sesarmid crab that inhabit at nipa palm (Nypa fruticans) forest and known as herbivorous animal. The feeding ecology of this crab are literally scarce. Therefore, this study was carried out to investigate the feeding behaviour of $L$. politum towards different type of nipa leaf condition and various food materials through a series of laboratory feeding-preference experiments; leaf preference and multiple-choice feeding experiment. Total of 16 crabs (male $=8$, female $=8$ ) were placed individually in glass aquarium. Leaf preferences of $L$. politum were determined on three choices of nipa leaf condition (fresh=green, senescent=yellow and decayed=brown) in which the choices were given for each crabs. Results showed that this crab significantly preferred green leaf over yellow and brown leaf. Meanwhile, for multiple-choice feeding experiment, the crabs were given other choices of food materials: mangrove slug, cricket, bee and green nipa leaf. Consequently, L. politum preferred animal materials over green leaf, thus provides evidence that even though in the natural habitats they are herbivorous, this crab can be shifted towards opportunistic omnivores with strong preferences for animal food. These results suggest that this crab play a greater role in nutrient cycling in the nipa forest.
\end{abstract}

Keywords: Sesarmid, food choices, experiment, nipa.

Abbreviations: L. politum $=$ Labuanium politum

LCR $=$ Leaf consumption rate

\section{Introduction}

The brachyuran crab of Family Sesarmidae has 32 genera and more than 250 species worldwide (Naruse \& Ng, 2012; Brosing et al., 2014). In Malaysia and Singapore, there are 41 species of sesarmid crabs being recorded (Tan \& Ng, 1994). Majorly, mangrove sesarmid crabs consume significant amount of either mangrove leaf litter or detritus comprising decayed leaves (Micheli et al., 1991; Fratini et al., 2000). Sesarmid crab species prefer to select different mangrove leaf litter types and categories since their stomach contents analysis comprise 5595\% of leaf fragments (Thongtham et al., 2008). This further affects the rates of mineralisation in the mangrove nutrient cycling (Ravichandran et al., 2007).

Leaf eating sesarmids showed selective preference on leaf condition between green (fresh), yellow (senescent) and brown (decayed) leaves (Ashton, 2002; Ravichandran et al., 2006; Chen \& Ye, 2008). Most sesarmids Sesarma plicata, S. messa, S. smithii and $S$. catenata were reported preferring decomposed leaves compared to senescent and fresh leaves (Micheli, 1993a; Micheli, 1993b; Chen \& Ye, 2008; Bergamino \& Richoux, 2015). It is known that different leaf condition varies in the content of its nutritional value such as tannin and carbonnitrogen ratio $(\mathrm{C}: \mathrm{N})$, in which the tannin and $\mathrm{C}: \mathrm{N}$ ratio decreases as the leaf degrade (Chen \& Ye, 2008). However, leaf materials are known as an inadequate diet due to their low nitrogen content (Mchenga \& Tsuchiya, 2010). Therefore, it is believed the herbivorous crabs must supplement their diet with other high nutritional food sources (Skov \& Hartnoll, 2002).

This study focused on one of the treeclimbing sesarmid species, Labuanium politum. 
that are obligate to nipa tree. Study on stomach content analysis of wild-caught $L$. politum had successfully reveal their natural diet where they majorly consume plant and sediment materials (Alwie, 2020). Besides, it was found that $L$. politum also consumes animal materials from their natural habitats where this crab had been seen to prey on grasshopper in the mangrove of Philippines and Singapore (Ng et al., 2015). Occasionally, herbivorous sesarmid crabs tend to be shifted towards opportunistic feeder when animal materials were present (Erickson et al., 2008) and it is believed that additional nutrition can be obtained by feeding on the animal tissues (Giddins et al., 1986; Islam et al., 2008b).

Currently there is no study on the feeding preferences of L. politum. It is still remained unknown whether $L$. politum will show any preferences on leaf condition and exhibit opportunistic behaviour towards various food materials. Therefore, the studies were designed to investigate the feeding behaviour of $L$. politum towards different type of nipa leaf condition and various food materials. It is hypothesised that L. politum preferred all leaf condition equally and since L. politum is a herbivore, the crabs would have no preference on other food materials other than leaf. This information could provide a clearer understanding about the feeding preferences of $L$. politum and could be enhance for further related research which can contribute to diverse knowledge in mangrove crabs' ecology.

\section{Materials and Methods}

\section{Samples collection and experimental collection}

Labuanium politum samples were collected from the nipa palm forest (Nypa fruticans) in

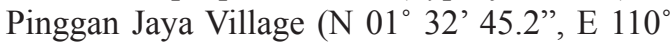
24 '36.5"), Kuching (Figure 1) on end March 2018. The experimental periods were carried out within two weeks. Crabs were collected using traditional gear, known as 'pengait'. Only alive and intact crabs with hard carapace and unberried females were used. A total of 16 adult individuals ( 8 males \& 8 females) with carapace width ranged $20-34 \mathrm{~mm}$ was selected in the experiment. All crabs were transferred to the laboratory in separate containers upon collection to avoid fighting between the crabs. Experimental materials which refer to the various types of food that will be tested to $L$. politum were also collected on the same site.

Three conditions of nipa leaves which is green=fresh, yellow=senescent and brown

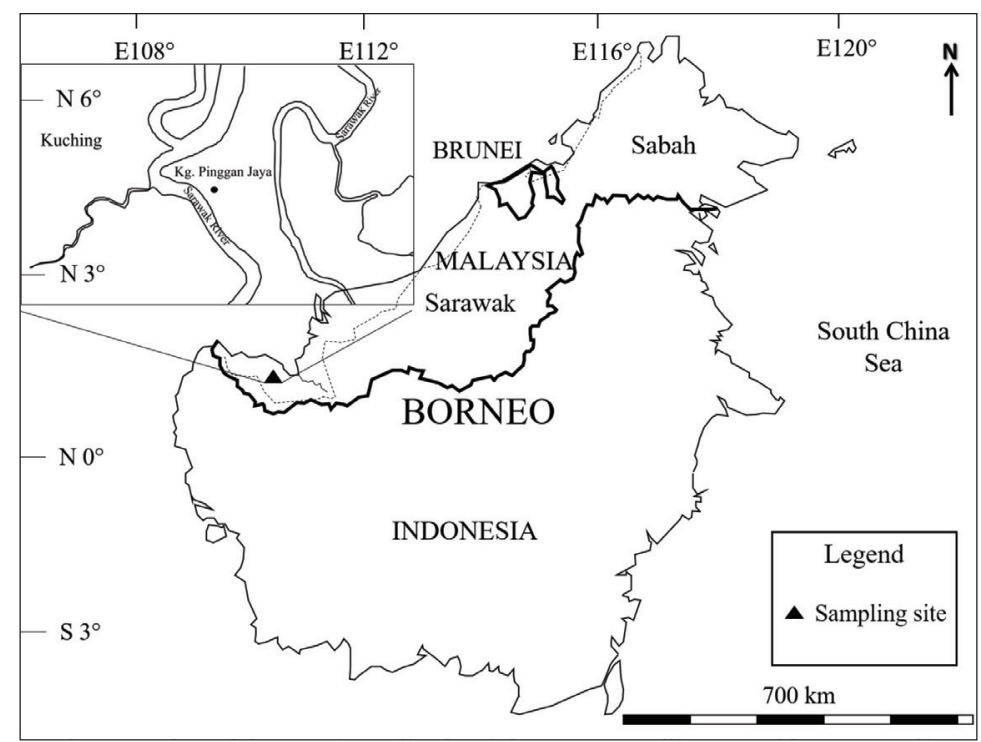

Figure 1: Sites of the samples collection (Pinggan Jaya Village, Kuching, Sarawak) 
$=$ decomposed were collected for leaf preference experiment. Green and yellow nipa leaves were handpicked from the trees, while for brown leaves were collected from the nipa forest floor. All the leaves conditions were freshly collected prior to the experiment.

Bee, crickets and mangrove slug were used for multiple choice feeding experiment. Bee and mangrove slug were collected in the study site while, crickets were purchased from pet shop. All animals offered were in intact condition except the mangrove slug which were cut into small pieces.

\section{Laboratory leaf Preferences Experiment}

To test L. politum preferences on nipa leaf conditions, the experiments were conducted in shaded places with a natural photoperiod $12 \mathrm{~h}$ light and $12 \mathrm{~h}$ dark for three days period. The experiments were conducted in 16 glass aquarium $(20 \times 20 \times 18 \mathrm{~cm})$ filled with $2 \mathrm{~cm}$ depth of wet mangrove sediment. The crabs were sprayed with brackish water daily to avoid desiccation. Single crab was placed in each aquarium and covered with steel mesh to prevent the crabs from escaping. Prior to the experiments, the crabs were acclimatised with the aquarium surrounding and starved to clear their guts from remaining foods for two days as suggested in Perisesarma bidens (Islam et al., 2008a). Leaves from each condition (green, yellow, brown) were cut into $2 \times 2 \mathrm{~cm}$ per pieces before being offered to the crab. This is to hinder the influence of leaf dimensions on the crab choice which analogous with experiment on Neoepisesarma versicolor (Thongtham et $a l ., 2008)$. Each crab were given three pieces of nipa leaves for each condition randomly which had been cut priorly (Figure 2).

The nipa leaves were priorly weighed up to three decimals places with analytical balance daily for the initial weight (gram). Nipa leaves were offered to the crabs at 1700 hour daily and left for 24 hours. After 24 hours, the remaining leaf materials were collected, blotted with paper towel, and the final weight (gram) were recorded to determine the leaf consumption rate. The steps above were repeated for three consecutive days. Leaf consumption rate (LCR) of the crabs for each leaf category were calculated and expressed in $\mathrm{g} /$ day as follows:

$$
\mathrm{LCR}=\frac{\sum \text { Mean of initial weight }(\mathrm{g})-\text { Final weight }(\mathrm{g})}{\text { Days of consumption }}
$$

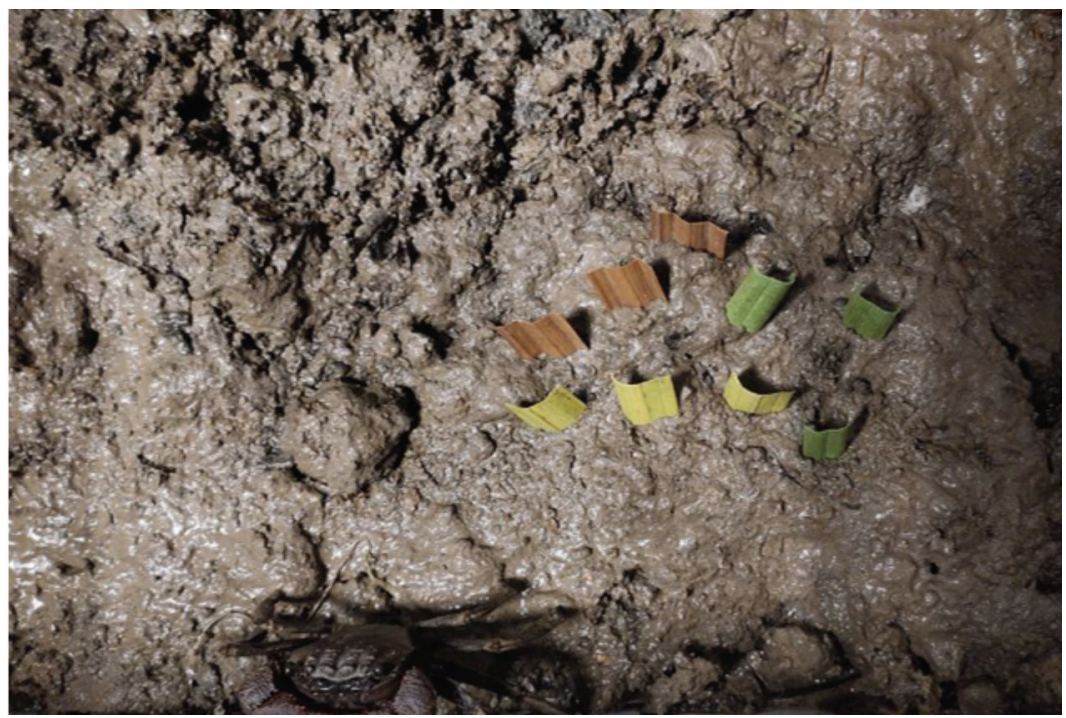

Figure 2: Experimental setup of $L$. politum in each aquarium with three leaf conditions offered 


\section{Laboratory Multiple-choice Feeding Experiment}

The aquarium setup was similar to the leaf preferences, except for the food materials offered. The experiments were conducted in three days period. Each crab was simultaneously offered with bee, mangrove slug, cricket and the most preferred leaf condition during leaf preferences experiment (green leaf) (Figure 3). Prior to the experiment, all crabs were starved again to clear their guts from remaining foods for two days. On the experiment day, the initial weights (gram) of all food materials to be given were taken before they were offered to the crabs. The food materials were given at 1700 hour daily and after 24 hours, the remaining of food materials were collected, blotted with paper towel and weighed its final weight. The above steps were repeated for three consecutive days. Total food consumption of each food category by crabs were calculated and expressed in (g/ day) as follows:
Then, the total food consumption results for each food category were standardised and expressed in percentage ( $\% /$ day) due to the different food dimension for each category.

\section{Statistical Analyses}

Leaf consumption rate was analysed for leaf preferences by all individuals of L. politum and between sexes using Kruskal-Wallis followed by post hoc Bonferroni (Giddins et al., 1986; Field, 2013). Meanwhile, the differences between each leaf condition by sexes were tested using MannWhitney test.

Total food consumption among food materials (bee, mangrove slug, crickets and one leaf category) by L. politum were tested using Kruskal-Wallis tests. All the statistics tested with 95\% confidence interval level (Zar, 1996).

$$
\text { Total Food Consume }=\frac{\Sigma \text { Mean of Initial weight }(\mathrm{g})-\text { Final weight }(\mathrm{g})}{\text { Days of consumption }}
$$

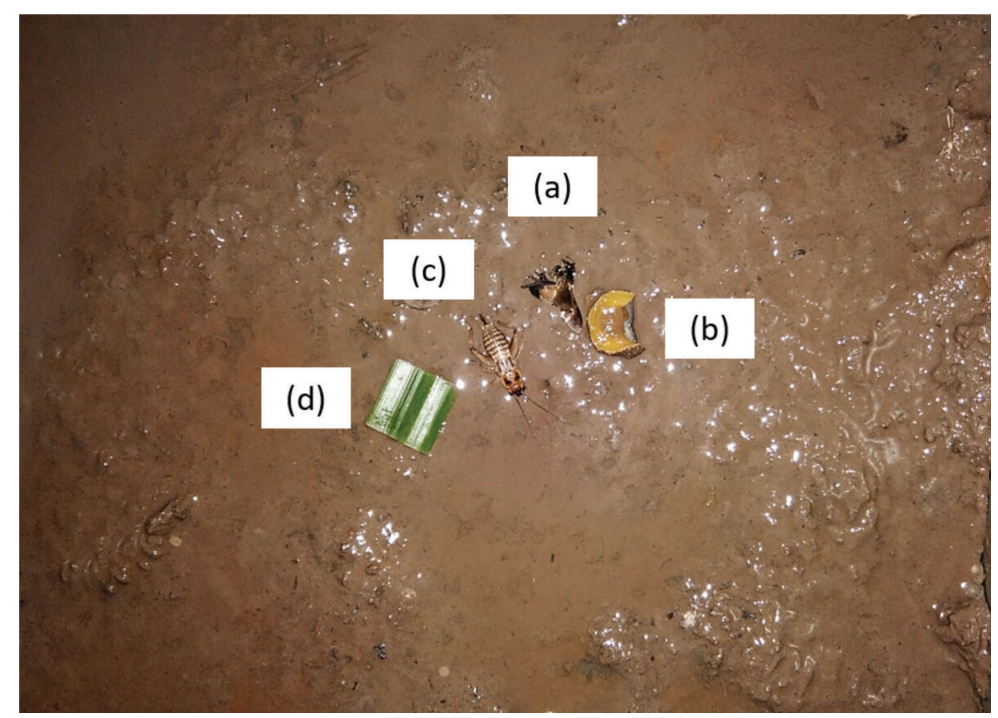

Figure 3: Experimental setup of L. politum in each aquarium with multiple-choice food. a) Bee, b) slug, c) cricket, d) green leaf 


\section{Results}

\section{Leaf Preferences Experiment}

The result showed no mortality throughout the experiment period and L. politum had a preference to green leaf with highest consumption rate $\left(0.018 \pm 0.012 \mathrm{~g} \mathrm{day}^{-1}\right)$ followed by yellow leaf $\left.(0.008 \pm 0.01) \mathrm{g} \mathrm{day}^{-1}\right)$ and brown leaf $(0.002 \pm$ $0.003 \mathrm{~g} \mathrm{day}^{-1}$ ) (Figure 4). There were significant differences between green leaf and the other two conditions, but yellow and brown leaves were consumed at similar rate (Kruskal-Wallis test, $\mathrm{H}$ (2) $=18.13, p=0.000)$.

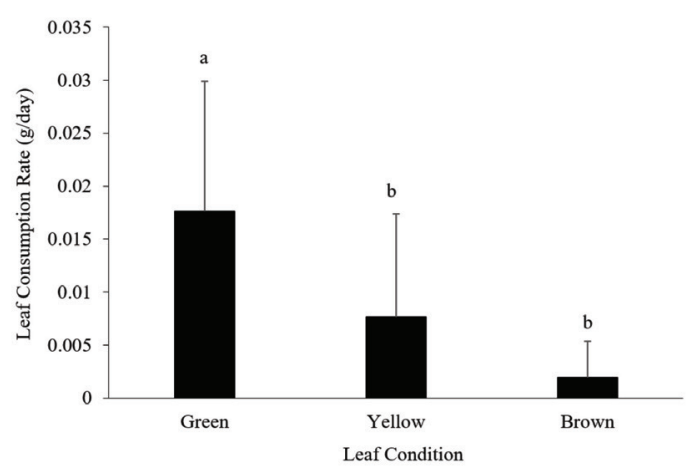

Figure 4: Labuanium politum mean leaf consumption rate $($ male $=8$ and female $=8)$ when offered with three $N$. fruticans leaf conditions (green, yellow, brown) simultaneously

Similar trend was observed when the results were analysed according to different sexes in which high mean consumption rate were recorded in green leaf followed by yellow and brown leaf. Male L. politum showed the highest mean consumption rate were green leaf $(0.022 \pm 0.013) \mathrm{g} \mathrm{day}^{-1}$ followed by yellow leaf $(0.012 \pm 0.01) \mathrm{g} \mathrm{day}^{-1}$ and brown leaf with $(0.003 \pm 0.003) \mathrm{g} \mathrm{day}^{-1}$ (Figure 5a). Female $L$. politum highest mean consumption rate was also green leaf $\left(0.013 \pm 0.009 \mathrm{~g} \mathrm{day}^{-1}\right)$ followed by yellow $\left(0.003 \pm 0.007 \mathrm{~g} \mathrm{day}^{-1}\right)$ and brown leaf $\left(0.001 \pm 0.004 \mathrm{~g} \mathrm{day}^{-1}\right)$ (Figure $\left.5 \mathrm{~b}\right)$. Both sexes showed a similar significant difference patterns which differ only between green and brown leaf (Kruskal-Wallis test: male, H (2) = 11.64, $p=$ 0.003 ; female, $\mathrm{H}(2)=10.16, p=0.006)$. Male L. politum showed the highest rates compared to female for all leaves condition. However, there was no significant difference between sexes in the preferences for each leaf condition (MannWhitney test, green $(p=0.142)$, yellow ( $p=$ $0.052)$ and brown $(p=0.318)$.

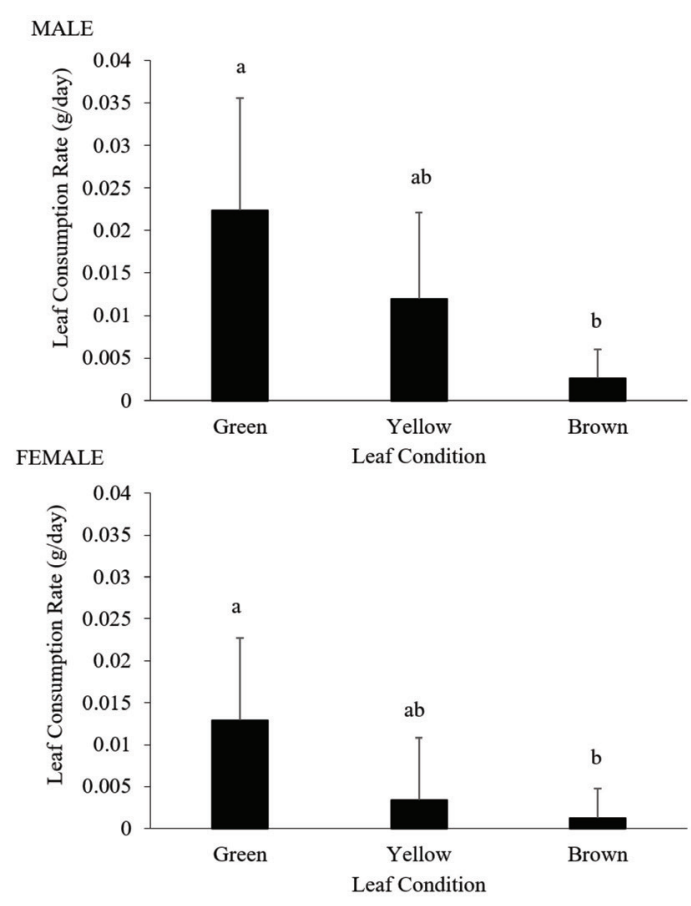

Figure 5: L. politum mean leaf consumption rates when offered three $N$. fruticans leaf conditions (green, yellow, brown), male $(\mathrm{n}=8)$, female $(\mathrm{n}=8)$ simultaneously

\section{Multiple-choice Feeding Experiment}

The result showed that L. politum highly preferred cricket $(44.23 \%)$ and followed by slug (37.86\%), bee (15.74\%) and green leaf $(2.17 \%)$ (Figure 6). There were significant differences of total food consume among all the food choices except between cricket and slug (Kruskal-Wallis test, $\mathrm{H}(4)=52.07, p=0.000)$.

Among the food consumed when offered with multiple-choices, both sexes showed least preferences towards the green leaf. However, the top three food preferences were different between male and female. The food preferences of male $L$. politum were highest for slug (46.63 $\%$ ) followed by cricket (37.46\%), bee (12.69\%) and green leaf (3.22\%) (Figure 7a). There were significant differences across all the food choices for male L. politum except between slug and 


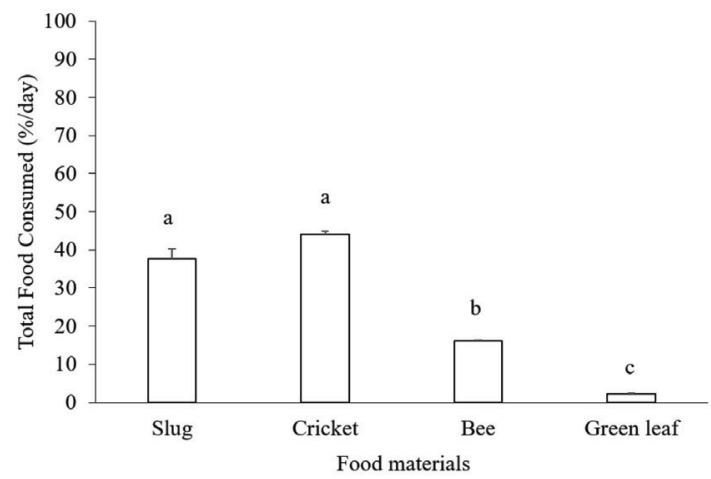

Figure 6: Feeding preferences of L. politum when offered with multiple-choice food materials (slug, cricket, bee and green leaf ( $N$. fruticans), $\mathrm{n}=16$. Different letters above the bars indicate significant differences among food materials

cricket (Kruskal-Wallis, $\mathrm{H}=33.85, p=0.000) . \quad=25.14, p=0.000$ ). When comparing the total Meanwhile for female, cricket $(58.29 \%$ ) was food consumed between male and female, there the highest in consumption and followed by bee was no significant differences between sexes in $(21.99 \%)$, slug $(19.71 \%)$ and green leaf $(0.02 \%)$ the preferences for each multiple-choice food (Figure $7 \mathrm{~b}$ ). There were significant differences across all the food choices for female L. politum materials (Mann-Whitney test, slug $(p=0.081)$, except between slug and bee (Kruskal-Wallis, $\mathrm{H}$ cricket $(p=0.052)$, bee $(p=0.083)$ except significant different in green leaf $(p<0.05)$.

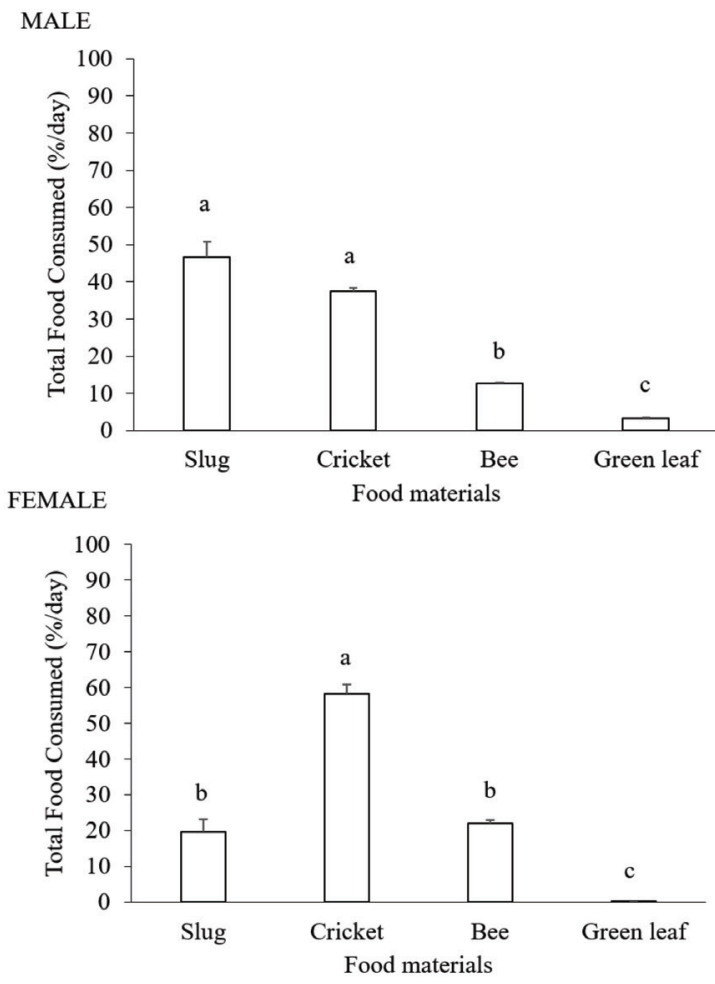

Figure 7: L. politum feeding preferences when offered with multiple-choice food materials (slug, cricket, bee and green leaf $(N$. fruticans), male $(\mathrm{n}=8)$, female $(\mathrm{n}=8)$. Different letters above the bars indicate significant differences among food materials 


\section{Discussion}

Current study is the first report on the L. politum feeding preferences in captivity. The leaf preference experiment revealed that L. politum prefer to consume green leaves than yellow and brown leaves. Although L. politum were fed in captivity, the preferences towards green leaf might be influence by their behavioural in the wild where it exhibits physical ability to climb and direct grazing on the fresh leaves at the nipa canopy. Furthermore, L. politum does not live up to the leaf ageing hypothesis since this crab does not bring the green foliage to their hiding place at the base of nipa frond and instead goes for direct grazing which reported in field observation ( $\mathrm{Ng}$ et al., 2015). Similar findings had been observed in other leaf-eating crabs species, namely ocypodid (Ucides cordatus) and sesarmid (S. eumolpe and S. onychophorum) which prefer fresh leaves (green leaves) and not relying on the ageing leaves (Ashton, 2002; Nordhaus \& Wolff, 2007).

The other assumption might be the ability of L. politum handling the toughness of green $N$. fruticans leaf. The fresh leaves were least preferred by sesarmids because of the toughness of the leaf and this was supported by Pennings et al., (1998) study which indicated feeding of leaf by crabs. On another study, feeding of leaf by crabs is positively correlated with decreasing of toughness of leaf that's explaining the preference of other sesarmids towards decaying leaf. This might be different to $L$. politum because of the chela has a spoon-like structure that very effective at pinching the green leaflet ( $\mathrm{Ng}$ et al., 2015). This reason might support the adaptation of L. politum to preferred on green leaf.

The other reason of $L$. politum preferred green leaf may be because they might possess digestive enzyme mechanism to break down the tannin. Green leaf is known to have high content in tannin and other crab species which preferred green leaf might have developed the mechanism to break down and utilize the tannins (Erickson et al., 2004). Furthermore, herbivorous crabs generally have specific adaptations in hindrance the negative digestive effects of tannin (Linton
\& Greenaway, 2007). This suggest that high tannins in green leaf does not affect the feeding behaviour of L. politum.

Moreover, green leaf has higher protein content and will decline or degenerate as the leaf ages to senescent and decaying leaf (Dhindsa $e t$ al., 1981). Through this, we can assume that $L$. politum might preferred green leaf which high in protein compared to yellow and brown leaf. Another reason that these crabs choosing green and yellow over brown because of the crab rely on the sense of sight for locating leaves, since green and yellow leaves are relatively more visible than brown leaves. This behaviour is seen on Parasesarma leptosoma and Neosarmatium trispinosum (Cannici et al., 2002, Harada \& Lee, 2016).

Both sexes of L. politum indicated no differences observed where both significantly preferred green and yellow leaves while brown leaves were the least preferred. This no distinct differences in preferences may be also because of the identical morphological characteristic that this crabs exhibit that gives them the same character not regarding sexes. In some crabs, there are differences in the feeding preferences between sexes for example, female $N$. meinerti, consume 4 times higher of green leaves than male where this proves other crabs exhibit sexes differences on leaf condition preferences (Olafsson et al., 2002).

Labuanium politum significantly preferred more on animals over green leaf. These results are similar to other findings where herbivorous crabs will opportunistically feed on animal matter when it becomes available and preferred more on them over plant materials (Beever et al., 1979; Erickson et al., 2008). Multiple-choice feeding conducted by Erickson et al. (2008), constructed the same result where sesarmid crab Aratus pisonii demonstrated to prefer animal matter (crickets) over leaf.

Sesarmid crab consumption on mangrove leaves are inadequate to fulfil the nitrogen requirement of crabs (Mchenga \& Tsuchiya, 2010). Therefore, to compensate nutrients that are not available from plant materials, the crabs 
obtained the nutrients they need by eating a varied diet that includes both animal and plant materials (Brousseau \& Baglivo, 2005). This shows that L. politum herbivorous behaviour will change when animal protein was available in the environment even though the plant material were present to compensate their insufficient nutrient. In addition, dead food materials supplied gives higher opportunity for $L$. politum to feed on animal materials throughout the experiments. Contrary to its natural habitats, the crab may be rarely feed on animal materials because of the difficulty to prey on animals and eventually may feeds highly on leaves due to its availability and highly abundant food source. The high preferences of L. politum towards cricket and slug may be because of its high protein content. But it will be more adequate to stand from the reasons if the protein content analyses were done for the food materials offered.

In this study, feeding preferences between sexes were found differs in terms of consumption rate towards the food materials. Male L. politum preferred slug and cricket the most and green leaf were consumed the least meanwhile for female, they strongly preferred cricket over all food materials. Hence, the predation of both sexes seems to focus on the animal materials over leaf. In other feeding studies, there were also variation observed in the rates of consumption and size preferences of food materials between male and female Asian shore crabs, Hemigrapsus sanguines (Brousseau et al., 2001). These variations were considered because of the differences in the differential energy and reproductive requirements (Cannici et al., 1996; Buck et al., 2003). This claimed suggest that maybe male and female L. politum have different nutritional demands and food processing. This experiment does not investigate the factors in food selecting of male and female L. politum and need to be further clarified.

\section{Conclusion}

In summary, L. politum showed preferences for fresh $N$. fruticans leaves. Furthermore, L. politum overwhelmingly preferred animal materials compared to green leaf, that provide evidence that even though their feeding habits are herbivorous in the natural habitats, L. politum can be shifted towards opportunistic omnivores with their strong preferences for animal food. However, other traits that determining the feeding preferences of $L$. politum should be considered and need a further study in aspect of nipa leaf condition (moisture, water content and nutritional value) to gain a better understanding on the feeding preferences of L. politum. Finally, this study can aid to understanding the true diet of L. politum.

\section{Acknowledgements}

Authors wished to thank the reviewers and editors for the comments on this article.

\section{References}

Ashton, E. C. (2002). Mangrove sesarmid crab feeding experiments in Peninsular Malaysia. Journal of Experimental Marine Biology and Ecology, 273, 97-119.

Alwie, N. A. M. A. (2020). Feeding preferences of an obligate aboreal crab Labuanium politum in selected nipa forests in Sarawak (Unpublished master's dissertation). Universiti Malaysia Sarawak, Malaysia.

Bergamino, L., \& Richoux, N. B. (2015). Food preferences of the estuarine crab Sesarma catenata estimated through laboratory experiments. Marine and Freshwater Research, 66, 750-756.

Brousseau, D. J., Fillipowiez, A., \& Baglivo, J. A. (2001). Laboratory investigations of the effects of predator sex and size on prey selection by the Asian crab, Hemigrapsus sanguineus. Journal of Experimental Marine Biology and Ecology, 262, 199 210.

Brousseau, D. J., \& Baglivo, J. A. (2005). Laboratory investigations of food selection by the Asian shore crab, Hemigrapsus sanguineus: Algal versus animal preference. Journal of Crustacean Biology, 25(1), 130 134. 
Brosing, A., Spiridonov, V. A., Al-Aidaroos, A. M., \& Turkay, M. (2014). Description of a new genus and a new species of Sesarmidae (Decapoda: Brachyura) from the Farasan Islands, Saudi Arabia, Red Sea. Journal of Crustacean Biology, 34, 273-282.

Beever, III., James W., Simberloff, D., \& King, L. L. (1979). Herbivory and predation by the mangrove tree crab Aratus pisonii. Oecologia, 43(3), 317-328.

Buck, T. L., Breed, G. A., Pennings, S. C., Chase, M. E., Zimmer, M., \& Carefoot, T. H. (2003). Diet choice in an omnivorous salt-marsh crab; different food types, body sizes, and habitat complexity. Journal of Experimental Marine Biology and Ecology, 292, 103-116.

Cannici, S., Dahdouh-Gubeas, F., Anyona, D., \& Vannini, M. (1996). Natural diet and feeding habits of Thalamita crenata (Decapoda:Portunidae). Journal of Crustacean Biology, 16(4), 678-683.

Cannici, S., Morino, L., \& Vannini, M. (2002). Behavioural evidence for visual recognition of predator by the mangrove climbing crab Sesarma leptosoma. Animal Behaviour, 63, 77-83.

Chen, G-C., \& Ye, Y. (2008). Leaf consumption by Sesarma plicata in a mangrove forest at Jiulongjiang Estuary, China. Marine Biology, 154, 997-1007.

Dhindsa, R. S., Plumb-Dhindsa, P., \& Thorpe, T. A (1981). Leaf senescence: Correlated with increased levels of membrane permeability and lipid peroxidation, and decreased levels of superoxide dismutase and catalase. Journal of Experimental Botany, 32(126), 93-101.

Erickson, A. A., Feller, I. C., Paul, V. J., Kwiatkowski, L. M., \& Lee. W. (2008). Selection of an omnivorous diet by the mangrove tree crab Aratus pisonii in laboratory experiments. Journal of Sea Research, 59, 59-69.
Erickson, A. A., Bell, S. S., \& Dawes, C. J. (2004). Does mangrove leaf chemistry help explain crab herbivory patterns? Biotropica, 36(3), 333-343.

Fratini, S., Cannici, S., Abincha, L. M., \& Vannini, M. (2000). Feeding, temporal, and spatial preferences of Metopograpsus thukuhar (Decapoda; Grapsidae): An opportunistic mangrove dweller. Journal of Crustacean Biology, 20(2), 326-333.

Field, A. (2013). Discovering statistics using IBM SPSS statistics ( $4^{\text {th }}$ ed.). Canada, Sage Publication Ltd. pp. 458-520.

Giddins, R. I., Lucas, M. J., Neilson, M. J., \& Richards G. N. (1986). Feeding ecology of the mangrove crab Neosarmatium smithii (Crustacea: Decapoda: Sesarmidae). Marine Ecology Progress Series, 33, 147155.

Harada, Y., \& Lee, S. Y. (2016). Foraging behaviour of the mangrove sesarmid crab Neosarmatium trispinosum enhances food intake and nutrient retention in a low-quality food environment. Estuarine, Coastal and Shelf Science, 174, 41-48.

Islam, M. S., \& Uehara, T. (2008a). Feeding habits of the sesarmid crab Perisesarma bidens (De Haan) in the mangroves of the Ryukyu Islands, Japan. Bangladesh Journal of Fisheries Research, 12(2), 213-224.

Islam, M. S., Mia, M. Y., Mahmud, S., \& Kamal, B. M. M. (2008b). Feeding habits of the Mangrove Sesarmid Crab Neosarmatium trispinosum (Crustacea) in the Ryukyu Islands, Japan. The Agriculturists, 6(1-2), 43-53.

Linton, S. M., \& Greenaway, P. (2007). A review of feeding and nutrition of herbivorous land crabs: Adaptations to low quality plant diets. Journal of Comparative Physiology, 177, 269-286.

Mchenga, I. S. S., \& Tsuchiya, M. (2010). Feeding choice and fate of organic materials consumed by Sesarma crabs Perisesarma bidens (De Haan) when offered different 
diets. Journal of Marine Biology, 2010, $1-10$.

Micheli, F., Gherardi, F., \& Vannini, M. (1991). Feeding and burrowing ecology of two East African mangrove crabs. Marine Biology, $111,247-254$.

Micheli, F. (1993a). Effect of mangrove litter species and availability on survival, moulting, and reproduction of the mangrove crab Sesarma messa. Journal of Experimental Marine Biology and Ecology, $171,149-163$.

Micheli, F. (1993b). Feeding ecology of mangrove crabs in North Eastern Australia: Mangrove litter consumption by Sesarma messa and Sesarma smithii. Journal of Experimental Marine Biology and Ecology, 171, 165-186.

Naruse, T., \& Ng, N. K. (2012). Establishment of a new genus for Cyclograpsus lophopus Nobili, 1905, within Sesarmidae Dana, 1851 (Crustacea: Decapoda: Brachyura). Zootaxa, 3572, 63-68.

Ng, P. K. L., Lee, B. Y., \& Tan, H. H. (2015). Notes on the taxonomy and ecology of Labuanium politum (De Man, 1887) (Crustacea; Decapoda: Sesarmidae), an obligate arboreal crab on the nipah palm, Nypa fruticans (Arecales: Arecaceae). Raffles Bulletin of Zoology, 31, 21-225.

Nordhaus, I., \& Wolff, M. (2007). Feeding ecology of the mangrove crabs Ucides cordatus (Ocypodidae): Food choice, food quality and assimilation efficiency. Marine Biology, 151, 1665-1681.

Olafsson, E., Buchmayer, S., \& Skov, M. W. (2002). The East African decapod crabs
Neosarmatium meinerti (de Man) sweeps mangrove floors clean of leaf litter. Ambio, 31, 569-573.

Pennings, S. C., Carefoot, T. H., Siska, E. L., Chase, M. E., \& Page, T. A. (1998). Feeding preferences of a generalist salt-marsh crab: relative important of multiple plant traits. Ecology, 79(6), 1968-1979.

Ravichandran, S., Kannupandi, T., \& Kathiresan, K. (2006). Mangrove leaf litter processing by sesarmid crabs. Ceylon Journal of Science (Biological Science), 35(2), $107-$ 114.

Ravichandran, S., Anthonisamy, A., Kamupandi, T., \& Balasubramaniam, T. (2007). Leaf choice of herbivorous mangrove crabs. Research Journal of Environmental Sciences 1(1), 26-30.

Skov, M. W., \& Hartnoll, R. G. (2002). Paradoxical selective feeding on a lownutrient diet: Why do mangrove crabs eat leaves? Oceologia, 131, 1-7.

Tan, G. C. S., \& Ng, P. K. L. (1994). An annotated checklist of mangrove Bracyhuran crabs from Malaysia and Singapore. Hydrobiologia, 285, 75-84.

Thongtham, N., Kristensen, E., \& Puangprasan, S-Y. (2008). Leaf removal by sesarmids crabs in Bangrong mangrove forest, Phuket, Thailand; with emphasis on the feeding ecology of Neoepisesarma versicolor. Estuarine, Coastal and Shelf Science, 80, 583-590.

Zar, J. H. (1996). Biostatistical analysis. Prentice Hall: Upper Saddle River. 